УДК 78.01/.071.1+781.9/.68/.61

DOI https://doi.org/10.31723/2524-0447-2020-31-2-15

\title{
У Юйан
}

ORCID: 0000-0002-5510-0418

здобувач кафедри історії музики та музичної етнографіі

Одеської національної музичної академії імені А. В. Нежданової

747354771@qq.com

\section{СЕМАНТИКА МОТОРНОСТІ У ФОРТЕПІАННІЙ МУЗИЦІ: ЖАНРОВЕ ПОХОДЖЕННЯ ТА СТИЛЬОВА ЕВОЛЮЦІЯ}

Мета дослідження - визначити основні історичні етапи та жанрові чинники розвитку семантики моторності у фортепіанній музиці, виявити функціональну та смислову множинність моторного тематизму як зумовленого ідеєю відтворення в музиці багатства рухової енергії людини. Методологія роботи зумовлюється єдністю історіографічного та семантичного підходів, передбачає поглиблення текстологічних оцінок та індивідуально-стильових характеристик. Наукова новизна даної статті зумовлюється тим, що вивчення сфери фортепіанної моторності надає можливості виявляти специфічні ігрові семантичні показники музично-виконавського процесу та музичного тексту, підтверджувати наявність у музиці образного віддзеркалення антиномій порядку - свободи, відсторонення - прийняття, дієвості ілюзорності, завершеності - відкритості, наслідування - винаходу, втілення - перевтілення, деяких інших. Розкривається єдність технологічних умов та образно-рольового призначення тематизму «загальних форм руху», його фундаментальне значення для фортепіанної поетики. Висновки. Найбільш результативним положенням щодо матеріалу даної статті є те, що «загальні форми руху», які буквально відтворюють енергію моторної сфери, тобто кінетику музичного звучання й відбиття в ній динамічності життєвого процесу, припускають предметну конкретизацію усередині загального семантичного поля даної музично-текстової сфери. Від ранньої класицистської епохи семантика моторності передається бетховенській поетиці, а далі - романтичному способу відтворення динаміки буття, на основі певних жсанрових форм та їх фактурно-тематичних принципів, тобто більще залежить від спільних композиторських рішень; у період пізнього романтизму й далі домінуючим у сфері моторного тематизму з його семантичними функціями постає індивідуальне авторське стильове начало, тому семантика моторності набуває більш диференційованих форм, залишаючись, однак, найбільш широким базисом музичного мислення й мовлення.

Ключові слова: семантика моторності, семантичні функції тематизму, фортепіанна поетика, фортепіанний тематизм, «загальні форми руху». 
Wu Yuyang, Applicant at the Department of Music History and Musical Ethnography of the Odessa National A. V. Nezhdanova Academy of Music

Semantics of motority in piano music: genre origin and style evolution

The purpose of the study is to determine the main historical stages and genre factors in the development of motor semantics in piano music, to identify the functional and semantic multiplicity of motor themes as conditioned by the idea of creating a wealth of human motor energy in music. The methodology of work is determined by the unity of historiographical and semantic approaches, involves the deepening of textual assessments and individual stylistic characteristics. The scientific novelty of this article is due to the fact that the study of piano motor skills provides an opportunity to identify specific game semantic indicators of the musical performance process and musical text, to confirm the presence in music of figurative reflection of antinomies of order freedom, removal - acceptance, effectiveness - illusory, completeness openness. imitation - invention, embodiment - reincarnation, some others. The unity of technological conditions and figurative-role purpose of the theme of "general forms of movement", its fundamental significance for piano poetics is revealed. Conclusions. The most effective position on the material of this article is that "general forms of movement", which literally reproduce the energy of the motor sphere, ie the kinetics of musical sound and reflect the dynamics of the life process, involve subject concretization within the general semantic field of this musical-textual sphere. From the early classicist era, the semantics of motor skills are transferred to Beethoven's poetics, and then to the romantic way of reproducing the dynamics of existence, based on certain genre forms and their textural-thematic principles, ie more dependent on common compositional decisions; in the period of late Romanticism and further dominating in the field of motor themes with its semantic functions appears individual authorial stylistic principle, so the semantics of motor skills acquires more differentiated forms, remaining, however, the broadest basis of musical thinking and speech.

Key words: semantics of motor skills, semantic functions of thematics, piano poetics, piano themes, "general forms of movement".

Актуальність статті та напряму дослідження визначається важливістю моторно-ігрового походження фортепіанного тематизму, у якому яскраво віддзеркалюється рухова природа музики - і суто технологічна, і смислова, тобто така, що виявляє способи безпосередньої участі людини у процесі створення музики, і така, що виявляє відсторонене смислове призначення музичної образності. Опосередковано до явища «музичних рухів» звертаються багато дослідників, зокрема тих, хто досліджує прояви у музичному тематизмі так званих «загальних форм руху», починаючи від ранніх барокових клавірних творів й завершуючи складними метаморфозами загальних формул руху у тематизмі композиторів XX століття 
(зокрема, це В. Бобровський, Є. Назайкінський, О. Самойленко $[1-2 ; 5 ; 6])$. Але окрема завершена концепція музичної моторності, зокрема d галузі фортепіанної музики, ще не створена, хоча дисертаційні дослідження останніх років містять деякі підходи до неї (зокрема це дослідження Л. Шаймухаметової, Ма Сінсін, Ян Веньянь [8; 4; 9]).

Мета статті - визначити основні історичні етапи та жанрові чинники розвитку семантики моторності у фортепіанній музиці, виявити функціональну та смислову множинність моторного тематизму як зумовленого ідеєю відтворення в музиці багатства рухової енергії людини.

Основний зміст статті. Якщо розглядати явище моторності у цілому, так би мовити sз загальної історичної позиціï, то виявляється, що до сфери моторності, яка репрезентує можливості, діапазон тематичного змісту текстової основи музики, утвореної «загальними формами руху», примикають багато мотивних комплексів, що будуються на «загальному звучанні», але вже є стилістично конкретизованими текстовими синтагмами, такими як концертність (у вузькому значенні), фуговані побудови, прелюдійність, токкатність, маршовість, скерцозність, етюдність, екзерсисність, баладність, ноктюрновість, «фоновость», і деякі інші, суміжні (див. про це: [6]). Причому для семантичних позицій моторної сфери характерне освоєння не лише просторового, а й композиційно-часового обсягу музики, темпо-ритмічних можливостей, фактурних контрастів, що підказує думку про її спорідненість 3 явищем гри, а також нагадує, що гра - це, насамперед, структурування часу, з психологічної точки зору. Як виявляє дослідження О. Самойленко, стилістичний зміст моторності, орієнтований на тематизм «загальних форм руху», передбачає швидкість, «змагальність», протиставлення континуумності й дискретності, буквальне «наслідування» - імітування й «винахід» - інвенційність; багатоголосся з індивідуацією функцій окремих голосів, рівновагу горизонталі й вертикалі. Суттєвою стороною стає також «абсолютна» музикальність - інструментальна «чистота» текстових формул, автономія структурних закономірностей як «правил гри», насамперед, повторення й розрізнення, самоцілісність технічних прийомів як показників майстерності (віртуозності), освоєння драматичної опозиції, конфліктності у зв'язку зі специфічною композиційною «сюжетністю» [6, с. 154]. 
Але ці загальні, саме виконавсько-жанровою специфікою музичної творчості зумовлені показники моторності уточнюються й поглиблюються всередині кожного музичного твору, залежно від індивідуальних авторських стильових уподобань, тобто отримують образно-смислову, концепційну диференціацію, різноманітні семантичні функції. Як справедливо зауважує Л. Шаймухаметова, принцип сполучення інтонаційної формули як конкретизованого предметно-характеристичного уявлення та типових формул «загального руху» всередині моторно-рухової сфери дозволяє створювати різні семантичні модифікації тематичного матеріалу музичного твору.

На іiі думку, вертикальна й горизонтальна комбінація в темі формульного типу інтонаційної лексики «загальних форм руху» надає музичному тексту особливих семантичних конфігурацій, причому, образна функція «загальних форм звучання» може бути як явною, так і прихованою, як правило, пов'язаною з ефектом «схованої поліфонії».

Ряд продуктивних, положень, висунутих даним автором, дозволяє знаходити ті параметри оцінки семантики моторності на достатньо ранньому етапі іiі розвитку, у бароковій клавірній сонаті (див. [8, с. 26-34]), які можливо адресувати й подальшому розвитку фортепіанного тематизму.

Зокрема, відзначимо, що від ранньої класицистської епохи моторний спосіб темоутворення передається бетховенській поетиці, а далі - романтичному способу відтворення динаміки не тільки зовнішніх природних процесів, але й внутрішнього світу, душевного життя особистості, причому в останньому випадку сфера «загальних форм звучання» набуває нової контрастності, підсилює свою потенційну драматичність (яскравим прикладом може служити фортепіанна творчість Ф. Шуберта, Р. Шумана, Ф. Шопена). Становлення моторного тематизму в музичній формі та в історичному часі пов'язане з явищем виконавської інтерпретації, оскільки саме вона може виявити, репрезентувати семантичні функції музичного звучання - або музичної теми як звучного феномена, за допомогою прийомів артикуляції, посиленої фразовими наголосами, агогіко-інтонаційними об'єднаннями й протиставленнями, внаслідок чого дані прийоми також долучаються до тематичних фортепіанних комплексів. Класико-романтичний період історії фортепіанного мистецтва впевнено довів, що образи руху є семантичною основою не лише моторності, але 
й усього музично-текстологічного простору, з його реальними та ідеаційно-віртуальними складовими, у цілому. Значення рухової активності музичного тематизму є настільки великим, що саме вона лежить в основі вихідної семантичної установки музичного тексту - установки на відносини з часом та з людським мисленням - уявою, на просування образної системи музики убік і екзистенційного узагальнення, і психологічної конкретизації людського досвіду.

Можна припустити, що «загальні форми руху», саме як загальні форми звучання, є знаковими універсаліями музики в $\dddot{11}$ художньо абсолютній, тобто «чистій», формі. Іншими словами, вони виступають загальної логіко-композиційною основою музичного тематизму в його іманентній художній якості, а найголовніше - виражають головне образне призначення музики, визначають іiі фундаментальні образні ресурси, солідаризуючись з ідеєю життя як руху, що прагне від хаотичної форми перейти до розумного порядку, тобто стати самозростаючим логосом.

Не менш цікавою та складною постає проблема структурних модифікацій моторного тематизму. Спостереження над музичним матеріалом вказують на необхідність враховування протилежних семантичних ситуацій, пов'язаних зі змінами структури «загальних форм руху» у контексті теми. Специфіка їх полягає в тому, що в концентрованих й просторово обмежених композиційних масштабах можливі взаємні перетворення інтонаційно визначених, індивідуалізованих формул та загальних форм руху.

Так, Л. Шаймухаметова звертається до творчості Д. Скарлатті та знаходить у його клавірних сонатах процес семантичних перетворень «загальних форм руху» в інтонаційні формули (абстрактного у конкретне) і процес проростання інтонаційних формул у «загальні форми руху» (конкретного в абстрактному). Зокрема, вона звертається до аналізу сонат № 9, 51, 70, 127, 162, 174 і вказує, що в їх тематизмі відбувається семантичне перетворення визначеної інтонаційної формули на інтонації-кліше «загальних форм руху» моторно-рухового характеру. Виявляється, що модифікації інтонаційних формул у сонатах пов'язані з їх серйозними перетвореннями в тексті - наприклад, руйнуванням структури, що приводить неминуче до десемантизації формул. Так, у темах сонат 19, 105, 169 відбувається характерний процес «стирання» інва- 
ріанта інтонаційної формули «фанфари» і перетворення ii на загальні форми руху, при цьому первинні значення «лексеми» також нівелюються. Перетворення «фанфар» на «загальні форми руху» і процес десемантизації усередині теми відбувається за рахунок дроблення основних інтонацій мажорного тризвуку-сигналу на не менш активні, ритмічно зменшені вдвічі гармонійні фігурації. У цьому випадку структурні модифікації знаку, що приводять до його десемантизації, організують у тексті процес перетворення формули на нейтральний художній елемент.

Іншим проявом семантичної взаємодії стає поєднання інтонаційної динаміки «загальних форм руху» 3 властивою їм моторикою руху, з одного боку, та інтонаційної формули, що представляє образність, предметність (зображального типу) зовнішнього світу, 3 іншого. В усякому разі, сполучення в часопросторі музичної теми двох типів тематизму - конкретного, що репрезентує «мігруючу інтонаційну формулу», i абстрактного, у вигляді загальних форм руху, стає типовою як для сонат Д. Скарлатті, так і пізніше, для клавірної творчості Й. Гайдна та В. Моцарта. Специфіку перебудування типу моторики у тематизмі зумовлює внутрішня текстова «гра»поєднання - протиставлення різнорідних фактурних позиції, способів експресії, зокрема горизонтального (послідовного) i вертикального (одночасно-симультанного), що відповідають образно-смисловій системі координат в музиці.

У творчості Д. Скарлатті переконливим прикладом вертикального сполучення музично-риторичної фігури і стереотипних «загальних форм руху» є тема сонати № 58, у темі якої в одночасності сполучаються два протилежні смислові елементи музичної мови: конструктивна основа, представлена фігурою сходження у верхньому голосі, й пропонуючий колорування інтонаційної формули нижній голос, виражений за допомогою «спиралевидного руху». Окрім цього, принцип сполучення інтонаційної формули предметно-характеристичного типу та стереотипних «загальних форм руху» створює особливий художньо-естетичний контекст мінливого настрою. Сполучення, або «змішання», образна контамінація $\epsilon$ одним із провідних принципів поетики бароко, що впливає на процеси внутрішньої семантичної трансформації музичного тексту, зокрема зумовлює ефекти поєднання «об'єктивного» (предметного) і «суб'єктивного» (емоційного, афекто- 
ваного) [8, с. 32-34]. Прикладами використання «загальних форм руху», у контексті яких формується нова контрастна семантика, можуть служити також сонати № 68, 97,132, 190, 191, 198, 200 Д. Скарлатті.

Саме 3 розвитком даної «схованої семантики», а також з ускладненням інтонаційних конфігурацій загальних форм руху пов'язаний їх подальший розвиток у фортепіанних сонатах Л. Бетховена. Зокрема, в сонатних циклах Бетховена фактурно-гармонійні способи організації музичної тканини, які засновані на загальних формах рухи, розширюють свій смисловий діапазон, виявляються здатними виражати контрастні образні позиції, а сам фактурний контраст набуває знакової функції здійсненої дії, події, особистого вчинку; крім того, саме дані динамічні тематичні ресурси дозволяють Бетховену укрупнювати фортепіанний штрих, надавати фортепіанному письму оркестрового масштабу. Складна комбінаторика інтонаційних складових частин тематичної побудови дозволяє варіювати семантичні наголоси, постає передоднем полістилістичного наповнення романтичної музики.

Дані зміни в характері тематизму стають і змінами у виконавській стилістиці, дозволяють говорити про більш високі емоційну напругу та контрастність, з якими пов'язана виконавська форма бетховенських сонатних опусів.

Цілком закономірно, що, успадковуючи й перетворюючи бароково-класицистські мовні реалії, композитори ХХ століття, неокласики передусім, звернулися до «формул руху»: вони не тільки містили дух часу, що породив автономне академічне музичне мистецтво; вони виражали й вільний «дух музики», який вперше, після певних настанов строгої ренесансної поліфонії, відкрив красу ігрової концептуалізації музичної форми.

Так, у творчості П. Хіндеміта застосування загальних формул руху в їх бахівському різновиді стає основою використання поліфонічного методу й доказу універсального значення рухливого контрапункту, як вертикального, так і горизонтального як особливої сфери музичної семантики. Композиційне рішення Хиндемита, відбите в циклі «Ludus tonalis», вказує на те, що він «бахівське» в музиці розуміє як широку сферу «гри» із часовими й просторовими способами організації музики, чому передує розуміння самих цих способів як «ігрових» і деіндивідуалізованих, тобто загальних - універсальних 
з логічної музичної точки зору, як в конструктивному, так і в художньому відношенні. Невипадково цикл носить підзаголовок «Тональні, контрапунктичні та піаністичні вправи». Проявляється в даному творі і властива мелосу Хіндеміта тенденція до абстрагованої музичної теми як жанрового «відволікання» в інтерлюдіях (алюзії жанрових, сюїтних переважно моделей бахівського й до-бахівського, куперенівського часу), як відродження неіндивідуалізованих тематичних принципів поліфонії строгого стилю у фугах.

Останнє, за слушним спостереженням В. Задерацького, зумовлене зростанням у композиції конструктивного фактору, коли «...сама конструктивна умова... претендує на роль смислового центру, що не терпить конкуренції. Це змушує відмовлятися від яскраво індивідуальної мелодики, здатної брати на себе значення смислового осередку. Наслідок цього - прагнення показати звукові ряди в умовах яскраво вираженої автономізації звуків, що сильно послабляє лінійну напругу...» [3, с. 147].

Звідси - важливість конструктивної новизни, що демонструє семантичну позицію Хіндеміта, з боку загальної концепції циклу, а також - ідея центрального тону, згортання тональності в один опорний тон, розкриття «гри тональностей» як гри звукотонових тяжінь, із боку системотворчого структурно-композиційного принципу. Завдяки тоновій багатозначності, хіндемітівська «тональність» асимілює різні ладові нахилення, між якими, у тому числі, між традиційними мажором і мінором, стираються семантичні відмінності (настільки важливі у бахівській музиці).

Відтак явище моторності перероджується у прийоми деіндивідуалізації тематизму та конструктивного перетворення мелосу. Це суттєво впливає й на розуміння тональності, тобто веде до засад процесу музичного мислення. Як пише Ю. Холопов, «матеріал, що належить будь-якій хіндемітівській тональності, сам по собі не може з повною безперечністю вказувати саме на цю тональність, а не на іншу» [7, с. 265]. Цілком ясно, що ставлення П. Хіндеміта до тематизму «загальних форм руху» має принциповий авторські-стильовий характер; це підтверджується циклом «Симфонічних метаморфоз», у якому композитор довільно поєднує музичні теми Вебера з чотириручного фортепіанного зошиту (ор. 60), а також фрагменти 3 музики до спектаклю «Турандот», таким шляхом переносить 
романтичного Вебера у музичні умови раннього музичного класицизму з властивою останньому схильністю до рухливоігрового начала та контрастно-складеної сюїтної форми.

Фактурно-ритмічне ускладнення, деяка тональна нестабільність, різноманітне темброве варіювання стають основними мовно-стилістичними способами композитора виразити своє відношення до ідей веберівських творів як до історичних універсалій музики, «загальних текстових місць» музичної композиції.

У такий спосіб, завдяки окремим авторським стильовим зусиллям, визначаються історико-семіологічні передумови формування специфічного стилістичного середовища фортепіанної музики, розширюється коло значень музично-тематичних загальних форм руху (загальних форм звучання) як базових текстових фігур, виявляється історична послідовність у придбанні ними нових мовних функцій, у тому числі, у зв'язку з появою нових жанрових різновидів фортепіанної музики, з розширенням відношення до піанізму як до мовного феномена, здійснюваного на власних інтерпретативних засадах, хоча й у діалогу з композиторськими ідеями.

Походження моторного типу фортепіанного тематизму, як прагматичної раціонально-логічної, водночас образно-смислової основи піанізму, пов'язане не лише з розвитком інструментального виконавства, що буквально спирається на гру, але й 3 актуалізацією власних семантичних властивостей музично-звукової моторності, тому відкриває суттєві психологічні підвалини музичного діяння.

Таким чином, наукова новизна статті зумовлюється доведенням, що вивчення сфери фортепіанної моторності надає можливості виявляти специфічні ігрові семантичні показники музично-виконавського процесу та музичного тексту, підтверджувати наявність у музиці образного віддзеркалення антиномій порядку - свободи, відсторонення - прийняття, дієвості - ілюзорності, завершеності - відкритості, наслідування - винаходу, втілення - перевтілення, деяких інших. Розкривається єдність технологічних умов та образно-рольового призначення тематизму «загальних форм руху», його фундаментальне значення для фортепіанної поетики.

Висновки. Найбільш результативним положенням щодо матеріалу даної статті $€$ те, що «загальні форми руху», які буквально відтворюють енергію моторної сфери, тобто кінетику музичного звучання й відбиття в ній динамічності 
життєвого процесу, припускають предметну конкретизацію усередині загального семантичного поля даної музичнотекстової сфери.

Різні «семантичні ситуації» (Л. Шаймухаметова) у сфері «загальних форм руху» розширюють їх образні функції та основні параметри оцінки семантики моторності, зумовленої даним видом тематизму.

Від ранньої класицистської доби семантика моторності передається бетховенській поетиці, а далі - романтичному способу відтворення динаміки буття, на основі певних жканрових форм та їх фактурно-тематичних принципів, тобто більше залежить від спільних композиторських рішень; у період пізнього романтизму й далі домінуючим у сфері моторного тематизму з його семантичними функціями постає індивідуальне авторське стильове начало, тому семантика моторності набуває більш диференційованих форм, залишаючись, однак, найбільш широким базисом музичного мислення й мовлення.

\section{СПИСОК ЛІТЕРАТУРИ}

1. Бобровский В. Функциональные основы музыкальной формы. Москва : Музыка, 1978. 336 с.

2. Бобровский В. Тематизм как фактор музыкального мышления. Очерки. Чайковский. Мусоргский. Скрябин. Рахманинов. Москва : КомКнига, 2013. Выпуск 2. 374 с.

3. Задерацкий В. Музыкальная форма. Вып. 1: Учебник для специализированных факультетов высших музыкальных учебных заведений. Москва : Музыка. 1995. 544 с.

4. Ма Сінсін. Текстологічні засади виконавської інтерпретації у фортепіанній творчості (від стилістичного змісту до семантичної типології). Дис. ...канд. мистецтв.; спец.: 17.00.03 - музичне мистецтво. Одеса, 2018. 187 с.

5. Назайкинский Е. Логика строения музыкальной композиции. Москва, 1982. $319 \mathrm{c.}$

6. Самойленко А. Музыковедение и методология гуманитарного знания. Проблема диалога: Монография. Одесса : Астропринт, 2002. $244 \mathrm{c}$.

7. Холопов Ю. О трех зарубежных системах гармонии. Музыка и современность. Вып. 4. Москва, 1966. С. 216-329.

8. Шаймухаметова Л. Семантические процессы в музыкальной теме : автореф. дис.... докт. искусствоведения; спец. : $17.00 .02-$ музыкальное искусство. Москва, 2000. 44 с.

9. Ян Веньян. Категория пианизма в контексте исполнительской типологии фортепианного творчества : дис. ...канд. искусств.; спец. : 17.00.03 - музичне мистецтво. Одеса, 2017. $191 \mathrm{c.}$ 


\section{REFERENCES}

1. Bobrovsky, V. (1978). Functional foundations of the musical form. Moscow: Muzyka [in Russian].

2. Bobrovsky, V. (2013). Thematism as a factor in musical thinking. Essays. Tchaikovsky. Mussorgsky. Scriabin. Rachmaninov. M.: KomKniga, Issue 2 [in Russian].

3. Zaderatsky, V. (1995). Musical form. Issue 1: Textbook for specialized faculties of higher musical educational institutions. M.: Music [in Russian].

4. Ma, Xinsin. (2018). Textological principles of performing interpretation in piano work (from stylistic content to semantic typology). Candidate's thesis of Arts; specials: 17.00.03 - musical art. Odessa [in Ukranian].

5. Nazaikinsky, Ye. (1982). Logic of the structure of musical composition. M. [in Russian].

6. Samoilenko, A. (2002). Musicology and the methodology of humanitarian knowledge. The problem of dialogue: Monograph. Odessa: Astroprint [in Russian].

7. Kholopov, Yu. (1966). About three foreign systems of harmony / Yu.N. Kholopov // Music and Modernity. Issue 4. M . P. 216-329 [in Russian]. 8. Shaimukhametova, L. (2000). Semantic processes in a musical theme. Doctor's thesis of Arts; specials: 17.00.02 - musical art. M. [in Russian].

9. Yang, Wenyang. (2017). The category of pianism in the context of the performing typology of piano creativity. Candidate's thesis of Arts; specials: 17.00.03 - musical art. Odessa [in Russian]. 